\title{
Ethnic Conflict and the Political Instability in Afghanistan
}

\author{
Muhammad Fahim Khan \\ PhD Scholar \\ Department of Political Science \\ University of Peshawar \\ fahimkhanjadoon86@gmail.com \\ Sajid Ali \\ Ph.D Scholar \\ School of Public Policy and Administration, \\ $X i$ 'an Jiaotong University \\ 28 Xianning Road West Xi'an, Shaanxi, P. R. China 710049 \\ msajidkhan201@gmail.com \\ Hashmat Ullah Khan \\ Ph.D Scholar \\ School of International and Public Affairs \\ Jilin University - China. \\ hashmat.kpk@gmail.com
}

\begin{abstract}
Over the last century, Afghanistan has been plugged by the local, national, and regional conflict that effectively handicapped the ability of the country to maintain the sovereignty of the country and protecting its citizens and their national interest. Ethnic conflict within the state jurisdiction causes unrest in Afghanistan that helps other regional and global powers to directly interfere in domestic policies. In addressing the need for political stability in Afghanistan, this article first examines the factors contributing to the country's current state of instability including the presence of religious militant groups and warlords struggling to maintain control. As a result of tribal and ethnic throughout the region causes political instability in Afghanistan. Next, this article addresses the need for cooperation among the tribal and ethnic groups for political stability in Afghanistan. Last, this article suggests ways in which Afghanistan may achieve political stability through the cooperation of ethnic and tribal groups. This article concludes that through encouraging cooperation




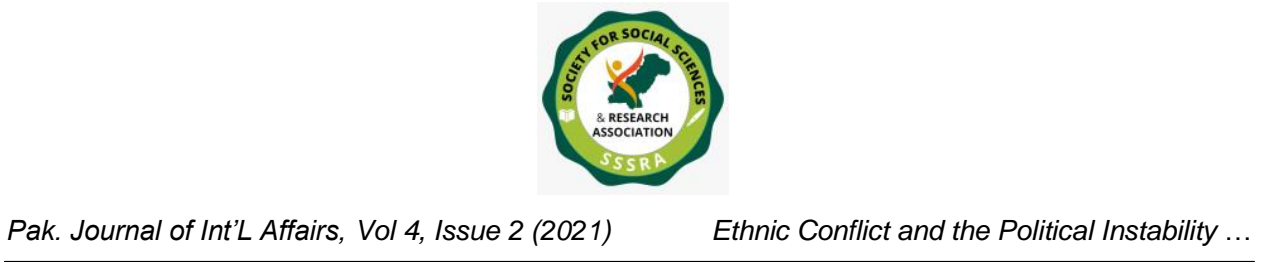

among the tribal and ethnic groups Afghanistan will likely become a more peaceful and politically stable country.

Key words: Afghanistan, Ethnic and Tribal conflicts, Political stability, Foreign Intervention

\section{Introduction}

Afghanistan came into being in 1747 as a state. Ahmad Shah Abdali was founder of Afghanistan. Afghanistan population is about 35.5 million, splitting more than fifty, in all into twenty ethnic groups, Pashto and Dari's are official languages of Afghanistan. Due to various ethnic groups, there are 30 other local languages speak in Afghanistan (Ewans, 2001). Pashtun are found in eastern and southern Afghanistan, and Pakistan's side has the same proportion of Pashtun across the Durand Line. As Durrani, who lives in between Kandahar and Herat, there are two subdivisions of Pashtun. Abdali is an ethnically Pashtun sub-tribe of the Durrani tribe.

In early days, Afghanistan was built under the supremacy of the Durrani tribes and was made up of territories occupied by the Durrani tribe or where Durranis ' power and control existed. Ghilzai, between Ghazni and Kandahar. With no end to confrontations and enmities, these tribes lived in southern Afghanistan. Mohmand, Mehsuds, Wazirs, Khattaks, Afridi and Shinwaris were in the eastern hills. They were known for their hostility and have been used for skirmishes across the northwest frontier by the British army. Tajiks are $1-5^{\text {th }}$ of the population based around Kabul, Kohistan, Herat, and Badakhshah.

They play a major role in the administration of the state. So it was simply a tribal state and its boundaries were not legally demarcated as such in the Northwest and Southeast. Under begs or amirs, Uzbek is semi-independent. Afghan Amir had conquered them. Most of them are peasants, breeders of horses and sheep of karakul. Hazaras are of mongol descent and descendants of Genghis Khan who arrived in the same age as flocks of thousands. Several people said they had moved from Central Asia. Most of them are breeders of sheep. All major ethnic groups are represented in the administration of Afghanistan as, for example, Pashtun is the president, finance and foreign minister, Tajik is the vice president and defense minister, Hazara is the second vice president, Uzbek is the minister of mine (Hanlon and Flourney, 2013). To grasp Afghanistan's ethnic conflict, it is best to view the history that led to the Panjdeh agreement and the Durand Line treaty which turned Afghanistan from a tribal state into a national state. 


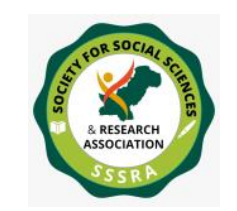

Ethnic Conflict and the Political Instability ...

In 1887 the north-western border of Afghanistan to Central Asia was demarcated by Afghanistan and Tsarist Russia in the Panijdeh Treaty. The frontier between Afghanistan and British India was demarcated in 1893 by the king of Afghanistan under the treaty of Durrand Road, Ameer Abdul Rehman. Ameer Abdul Rehman started the process of transformation of Afghanistan from a tribal state to a National State with defined and international frontiers. However, this wasn't an easy job. Under the Panjdeh Agreement, significant parts of Uzbek and Tajik territories had become part of Afghanistan.

Some of the largest Pashto groups of the British India Durrandline Agreement, including Yusufzais, Khattaks, Mehsuds, and many Wazirs, Shinwaris, Mehmunds, and Achakzais. But also Muslim, primarily Shiites and ethnic Mongols, were the Hazara tribes of Central Afghanistan. Therefore, it has not been very successful to turn a Pashtun tribal state into a national state. It only papered on a multi-ethnic, multi-sectoral political reality and on holes. Nonetheless, Afghan leaders have been able to achieve peace by rigid neutrality strategy, leading to a regional balance of power, in order to establish a delicate balance between Pashtun and the inter-ethnic tribal groups (Pashtun vs Tajic, Uzbek and Hazara tribals). Sardar Daud, who overthrow King Zahir Sha's throne in a military coup in 1973, split the intra-Afghan tribal and cultural unity and regional stability. Five years later, Sardar (President) General Abdul Qadir Dagarwal also destroyed Daud's government, and two obscure socialist parties were granted control by the Afghan army: Khalq (mostly dominated by Pashtun) and Parcham (mostly dominated by Uzbek and Tajik).

While Sardar Daud had undermined Afghanistan's precarious tribal equilibrium and national peace by taking a radical irredentist stand against Pakistan, Soviet intervention in Afghanistan (Dec 28, 1979) entirely demolished Afghanistan's unity and status as an unaligned neutral state. Apart from transitional government, there are various forces in Afghanistan. Ethnic conflicts between Pashtuns are mainly Taliban and minority Uzbeks and Tajiks from northern Afghanistan have delayed integration. This racial rivalry has also been compounded by the Opium trade. External actors have mistaken this solidarity, as well as race, in order to use and control oil resources. Disintegration is unacceptable not only for central Afghanistan, but also for regional countries and the international community, in general, to the Taliban's brutalities over their recent past tyranny, and even to the new insurgency.

Taliban's defeat has led to the division of the Afghan nation, and most likely it's better to say it's being bisected into Taliban and anti-Taliban with two different streams of living. Compared to Pashtun, Tajik and Uzbek dominated. Taliban and various 


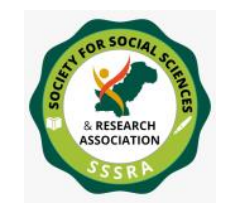

Ethnic Conflict and the Political Instability ...

factions have waged resistance against foreign forces, and warlords have further increased the pressure on the US (Samad, 2011). Many factors have destabilized Afghanistan's political structure as an ethnic conflict, poor governance, no effective public relations with the central government, and there is no secure legal dispensation at local level. The worst of all vested interests was in very unlawful fashion with enough weighting. On top it all, average Afghans are deprived their share, and the Taliban as well as regional power players are also in dire straits with their desire for peace and security (Brown, November 2012).

By political engagement, the U.S.'s goal was to change people's minds to deviate from the traditional Taliban residence and spread the Western culture there. This policy has been effective in Afghanistan, and Obama is leading the way in an ambitious style fashion, independent of the variable his government faced with more casualties than gains (Hilaly, 2012). Unless the strategic surroundings have turned into his favour, he will not consider tactical retreat. America's underlying political goal is to stop Russia, China, and Pakistan from joining Afghanistan in order to control both Afghanistan and Central Asian Republican's ' natural resources, which included gas \& oil (Ali, 2013). Karzai's government was created as a proxy by the US. The greatest fear of Afghanistan is ethnic conflict capable of undermining the political settlement. Despite Afghan forces through in scale, security in Afghanistan can not be ensured unless and until citizens are safe at the local level as well. Security and political stalemate may take place on the eve of withdrawal (Brown, 2012).

After the western departure, Afghanistan's main stack holders will be the Kabul government, the Taliban, and the neighbors of Afghanistan supported by the northern alliance (Nadir, 2013). The U.S. wants Zalmai Khalilzad on the verge of departure as persons carrying out the U.S. program, CIA aid, where they are not physically present, in Afghanistan. Aftab Sherpao, former interior minister, Rustam Shah Mohmand, former embassador for Afghanistan, and Hasan Askari Rizvi, defense analyst, said that the administration of Kabul, various Afghan Taliban militias, tribal chiefs and local Taliban commanders as main power holders will continue to be undertaken after the ISAF / United States / NATO pullout (Sherpao, Mohmand and Rizvi, 2013). In addition to Tajikistan, Uzbekistan, Turkamanistan, Russia, the United States, the United Kingdom and Saudi Arabia, international participants will be Pakistan, Iran (Munir, 2013). The new Afghan government's level of control over the country is modest and is likely to be limited after the US withdrawal. The Afghan Taliban will likely have more influence over broad areas of the country in the south, given Kabul not collapsing to them early (Mir, 2013). 


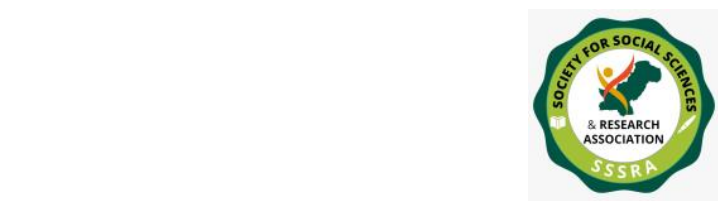

Ethnic Conflict and the Political Instability ...

The Afghan government received substantial sums of U.S.S.R. economic and military assistance and U.S. economic aid during the first three decades of the Cold War. Such funds allowed the state to pursue a limited number of modernizing education, communication, and industrialization projects requiring a closer relationship between the center and the periphery. Such undertakings are safeguarded by the extension of the state's coercive power. The 1978 overthrow of the Afghan monarchy, the 1979 Soviet invasion and the growing Soviet military presence in the 1980s culminated in the United States militarizing the Afghan region, aided by Saudi Arabia and Pakistan. The influx of large quantities of arms and funds intensified traditional ethno-linguistic, religious, and territorial tensions in Afghanistan and facilitated alternate peripheral social and political structures and local governance processes.

\section{Ethnicities in Afghanistan.}

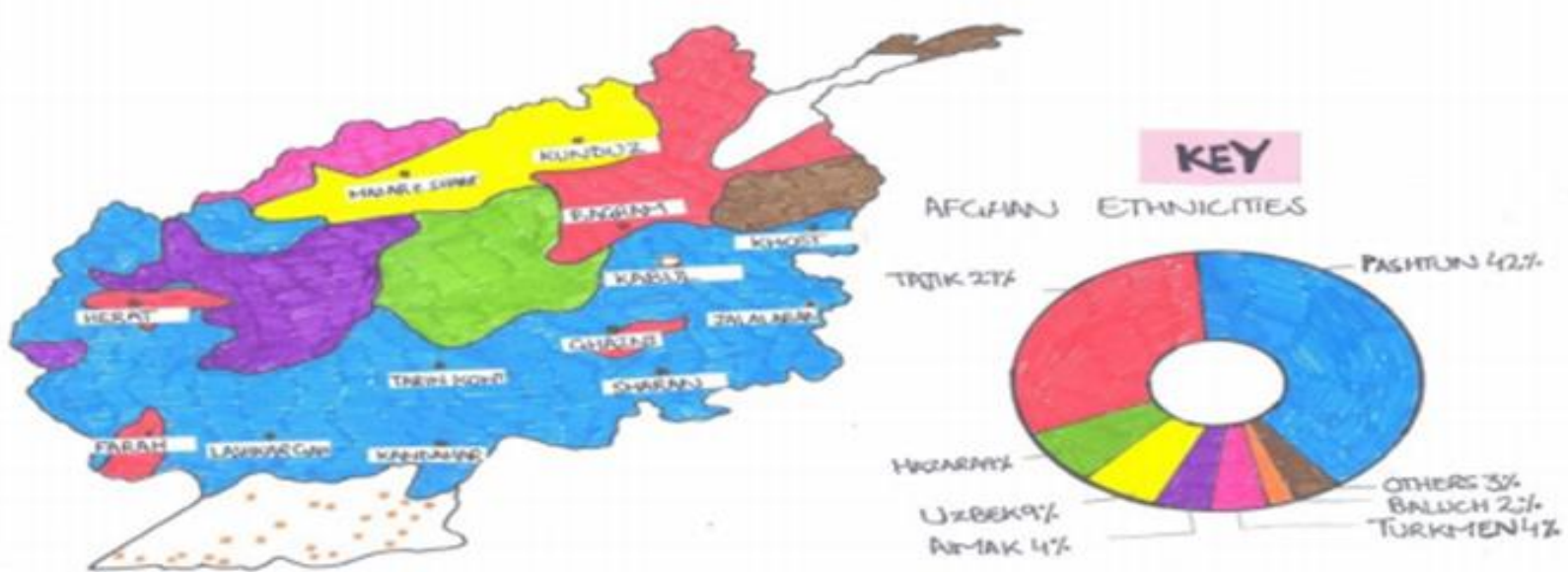

Source: Maps websites, intuitions of strategic United Kingdom books and journals.

Afghan politics have undergone many concurrent changes over the past 30 years. The power structure at the center has broken, allowing the connection between core and periphery to evaporate. Economic and human resource movement from different regions of Afghanistan to locations across international borders has intensified, particularly in Iran and Pakistan (Raufi, 2015). There has been a worsening of racial, religious and local cleavages. Islamist ideology has become increasingly rooted in the context of political discourse and procedures, and the Afghan periphery has become heavily armed.

\section{Factors Contributing in Political Instability in Afghanistan:}




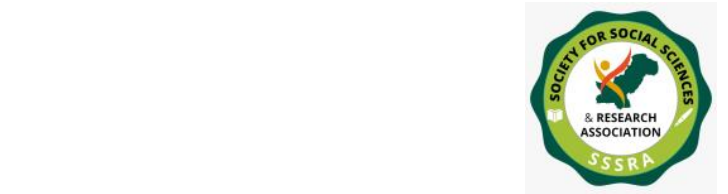

In the current political instability in Afghanistan, there are several factors that contribute multiple factors. Political scientists argue that increasing population density and frequency increases the risk of civil conflict. It could also lead to a greater possibility of demonstrations in non-democratic countries to overthrow government structures. This argument is not about the number of people who end up in an uprising, but only about the number of people that start it (Rashid, 2015). This argument has political scientists. Rebels are enough to pose a grave threat. The rural population of Afghanistan is a major driver of political stability.

Rural residents have primarily undermined the political stability of Afghanistan now and in the past. Today, nearly all insurgent groups like the Taliban live in rural areas. We hire terrorists and direct all their destructive actions against the state. As a significant example, many resistance groups were in rural areas during the war against the Soviets in Afghanistan (Raufi,2015). In 1996, when the Talibans conquested Kabul, nearly everyone from the rural communities were hired. Rural areas are safe havens where extremists can quickly and freely plan their disruptive acts (Rashid, 2015).

\section{Geography}

The rebellion is closely connected with the state's environment. Insurgents profit from the existence of rough terrain, not protected well by roads and far from the centres of state power. This is enhanced by the presence of people residing in cross-border sanctuaries that can be controlled effectively by local insurgents. It is not uncommon for these local populations to be caught between their obligations as natives and their tribal loyalty to national groups of insurgents (Raufi, 2015). Nevertheless, the State has no absolute control over these areas, which offers the rebel groups a decent atmosphere.

\section{Poverty}

People feel like their country has abandoned them and they have continued to provide financial resources to increase their living standards. The fact that a large proportion of young men in the country cannot find appropriate work in this industry is highlighting this issue (Raufi, 2015). We were highly underspend in spite of their contribution to economic development and political participation (Rashid, 2015). Afghan youth are more likely to take up financially unproductive practices such as the integration of gangs and drogue cartels, and to engage in politically disruptive behavior.

\section{Extremism}




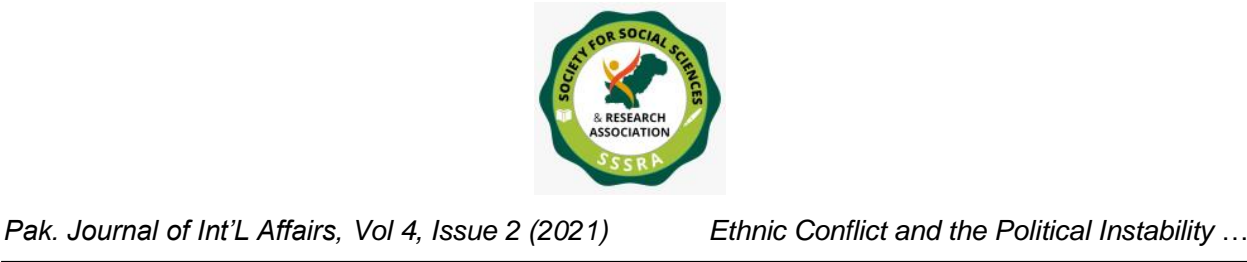

We know well that the center of many conflicts in Afghanistan has been religious extremism. Extremists justify their version of Islamic language to force people to accept the Islamic view. The reality that almost all rural residents are uneducated only exacerbates this problem. These were assisted by the existence of madrasas, Islamic colleges (Rashid, 2015). They extended their social radical thought primarily to the community in these schools. Radical Muslims play an important part in destabilizing practices in Madrasasa's commodities.

Recently, the number of insurgent attacks in the country has increased dramatically. The NATO-Afghan security forces and US pressure inspired the Taliban to escalate their brutal activity. The risk could reappear strongly (Raufi, 2015). The rural population has a significant impact on Afghanistan's political stability on the basis of these three factors. Unfortunately, this issue seems not to be taken very seriously by the government (Rashid, 2015). The country's decline and removal of US and NATO forces makes this risk very severe. Experience will repeat itself again if the state fails to address the issues.

\section{Tribal and Ethnic Conflicts}

At the beginning of modern times, a number of ethnic communities, who had little in common apart from Muslim faith, populated Afghanistan (Saikal, 2004). Afghan ethnic groups are "solid, border-divided, conflicting cultural units for years" (Shahrani, 1986). Ethnically, Afghanistan is "a diverse country at the edge of the Pashtun population, as all kings come from that group." However, before the Saur Revolution, caste had never been a very important element in Afghan politics (Rais, 1999). The Afghan war has changed the traditional power relationship between ethnic groups significantly. Yesterday, the populations in non-Pashto are smaller than 20 years ago.The population statistics of the main ethnic groups in the absence of a reliable official census is highly controversial. 
Table 1

\begin{tabular}{|l|l|}
\hline Ethnic Groups & Share (percentage) \\
\hline Pathans & $42 \%$ \\
\hline Tajiks & $27 \%$ \\
\hline Hazar & $9 \%$ \\
\hline Uzbeks & $9 \%$ \\
\hline Aimak & $4 \%$ \\
\hline Turkmens & $3 \%$ \\
\hline Balochi & $2 \%$ \\
\hline Others ethnic groups & $4 \%$ \\
\hline
\end{tabular}

Source: Youngerman, Barry \& Wahab, Shaista. (2007). A Brief History of Afghanistan. InfoBase

Publishing, New York. P. 14.

Few Afghan community groups are retaining ethnic uniformity outside the Pashtun provinces in the south and east and breakdowns are studied further (Debets, 1966c). For centuries, many races have miscegenated and there are mixed cultures with broad racial grey areas. Blue-or-mixed-eye variations occur in tandem with epicanthical folds and high cheekbones when there has been long interaction between Caucasoid and Mongolian communities, particularly between Tajik and Uzbek in North Afghanistan. There are also many darker-skinned people with black, green and blended eyes (Dupree, 2010).

Speculation and mythology are the origins of the various ethnic groups (Youngerman \& Wahab, 2007). As a result of the dynamics of the social, religious and linguistic multiplicity of the region, Afghanistan faced the political intricacies of "developing a cohesive nation-state." "Five major communities and hundreds of smaller ethnic groups, many of whom have not been formed," says Barfield.

\section{Pathans}

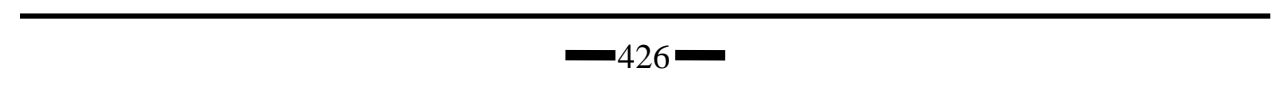




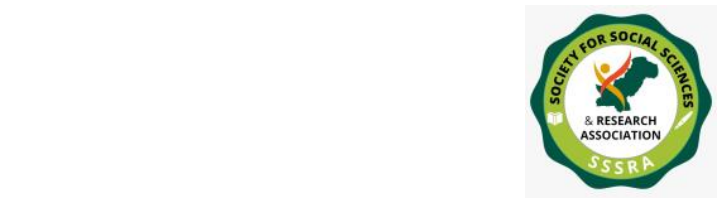

Although "traditional partnership within tribal social organizations is a key variable, Pastun is soon aware of the fact that these age-old connections have not been as respected as they used to be." (Ruttig, 2010). They are considered to be one of the "largest tribal societies in the world." We are the largest ethnic group within Afghanistan, representing between 50 and 54 percent of the total population, clustered in south and east Afghanistan. Since the mid 18th century, they have dominated (Hanley, 2011). Durrani and Ghilzai, which stretch to the south and east of the country, are their major Tribal confederations.

Both have each other's enmity. Mohmand, Afridi and Yusufzai are the other main Pashtun tribes. We all follow Pashtunwali's strict honor code. Pashtuns are known for their rigid division of duties, and women in their home compounds often remain isolated (Youngerman \& Wahab, 2007). The position of the Pashtuna in Afghan culture and the changing power system declined somewhat following the war (the Soviet invasion) and their subsequent political division between the tribes and hegemony over other ethnic groups (Newell, 1999).

\section{Tajiks}

Tajiks are the second largest ethnic group to join better educated and skilled, ranging from 26 per cent to $30 \%$. The Soviet war in Afghanistan and the civil war with Pashtoon brought the Tajiks to the stage. In the era of ' Post 9/11 ' they were still influential.

\section{Uzbek}

As an ethnic group of Uzbeks the Hindu Kush and the Central Asian region outside the Amu Daryas are situated in a major geopolitical context. One of the largest ethnic groups in Afghanistan is the Uzbeks, who make up approximately 8 percent of the total population. We came to the nation at that point as "the refuges and soldiers escaping the Russian armies and, eventually, the Soviet forces of Central Asia" (Rais, 2008). The invasion took place. As a second language, we still speak Dari, while common with Uzbeks (Smith, 1996).

\section{Hazara}

As they were not native people like Uzbeks, in the 13th century they arrived while "part of Genghis Khan's invading hordes." We make up 7\% of the total population, reside in Hazarajat and speak the Dari and Persian languages. Our ethnic group is the country's poorest and most oppressed (Rais 2008). 


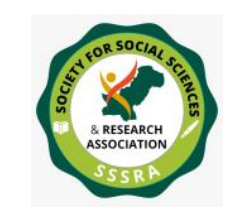

Pak. Journal of Int'L Affairs, Vol 4, Issue 2 (2021)

Ethnic Conflict and the Political Instability ...

\section{Aimaq}

They lie between West Herat and East Hazarajat and we speak Persian from half a million to three-quarters of a million. We were often classified into four clans;

- Jamshedis

- Taimani

- Taimuri

- Firozkohi (Rais. 2008)

\section{Others- Turkmen, Nuristanis, Balochis}

We comprise $4 \%$ of the total population. The Turkmen citizens are cross-border in Turkmenistan with a history, ethnicity and literature. Kafers (unbelievers) from Kafiristan, Pkaistan's northwestern zone, share culture and history of Nuristani. Nevertheless, the area was named Nuristan before Islamin was transformed in the late 19th century. Although Balochis is in common with the people of Balochistan's Pakistani province (Rais, 2008:). Civil wars emerged in Afghanistan as a consequence of "ethnic discrimination" in modern Afghanistan history because they think they are the rivals of striving to enter countries with power and control.

Internal and external influences were included. Wars, especially long, destructive, civil conflicts between groups, create or sharpen the existing ethnic identity of certain groups by exasperating a sense of loss and, at the same time, induce a real, imagined sense of empowerment. Afghan conflicts have changed radically the balance of power and authority between the social and political forces of the traditional government. Today, in the history of the country of their separate identities, the ethnic and social forces of Afghanistan are more aware than ever. Reactions to the Communist regime and the Soviet invasion are more or less ethnically or geographically orchestrated. Under their own ethnic leadership, they set up a kind of self-government by ousting their regions from the Communist State and its functionaries.

Instead racial factors led to political polarization between the Mujahid parties and forced them into a vicious power struggle after the collapse of the Marxist dictatorship (Rais, 2008). This rivalry, a multi-polar one, has taken on dangerous sectarian and regional dimensions, gradually becoming the ethnic dispute between Pashtun, the fear of power loss, and the Northern Uzbek-Tajik alliance, historically controlled by the Pashtun elite, which have gained greater political strength in Kabul. The Afghan parties could not negotiate effectively and maintain stable coalitions in the absence of a democratic institution, undermining national unity. The differences between majority and minority pashtun groups, on the one hand, and the political divide between traditional and 


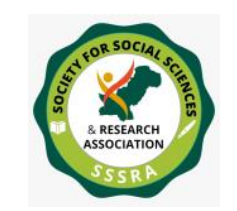

Ethnic Conflict and the Political Instability ...

revolutionary Islam parties, on the other, broadened resistance conflict after the Soviet Union, the common enemy. The Taliban rebellion, which was seeking reunification through military conquest and establishing a highly centralized state structure ruled by a rigid theocratic script, often originated from Pashtun's racial undertones. Its military attack pushed ethnic minorities out of the country, leading to the worst violations of human rights.

In favor of ethnic minority groups in the northern part of the country, the postTaliban political systems had been tilted. The political system of Afghanistan is becoming more democratic with its new Constitution and elections for parliament and for the provincial assemblies. Economic and political recovery can extend to ethnicity. However, it will take more to resolve ethnicity and the issue of national participation by looking for housing and functioning in a United States, as it was before war, by the social groups in Afghanistan (Rais, 2008). "Race group traits are all over the planet the same because parenthood is a variable in the identity of the tribe."

Regarding terms of "violence," ethnic groups have been important factors regarding Afghanistan's past (Hanley, 2011). Ethnic problems have a significant impact on the people of Afghanistan and can "lead" society to violence. Ethnic characteristics further deepen the rift between Pashtun and non-Pashtun groups, the so-called' insurgent forces challenge Afghanistan.'

- As far as agricultural activities were concerned, the partnership between rural Tajiks and urban Pashtuns was tense in Kunduz.

- Farmers from Uzbek and Hazara are in conflict with herders from Pashtun (Hanley, 2011).

\section{Cooperation Among Ethnic Groups Helps Political Stability in Afghanistan.}

Afghan ethnic groups has historically co-existed without a serious dispute about "problems of resources and recognition." Equality of the sexes has persisted with the' establishment and minority ' groups. The principle of balance is based on the harmony, balance and permanence of "ethnic group partnerships," and it is not based on any "cultural, financial or political impartiality," which in real social matters is barely possible. For over two centuries the Pashtun tribes, forming the Afghan system as a tribal confederation, subjugated the nation's super-structure with its fragmented existence (Rais, 2008). Ethnically Pashtun Afghan monarchs are unable to uphold political, moral and cultural values outside of Pashtun, the "East Pashtun Society on both sides of Afghanistan and Pakistan." In Afghanistan they adopted Persian with a differentiation 


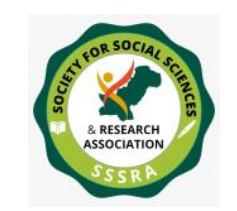

Pak. Journal of Int'L Affairs, Vol 4, Issue 2 (2021)

Ethnic Conflict and the Political Instability ...

between local dialect and intonation. They are known as Dari. For thousands of years, the Persian language and culture of the region have been continuous inscriptions on local populations, including Tajiks and the Afghan oligarchy in Afghanistan and beyond to Central Asia (Herzig, 2004).

It is uncertain whether in the 20th century the Kings of Afghanistan made any serious and systematic effort to create a cohesive, inclusive and national identity, representing cultural, tribal, and traditional forms of literary culture that many of Afghanistan's historians and observers today in society and politics conclude that Afghan nationalism and recognition of childhood are "the subject of discussion" (Ahady, 1995).

- Hospitality

- Giving Refugee

- Protection to fugitives

- Revenge (Rais, 2008).

That is why, more than other ethnic groups, Pashtun groups identified themselves with Afghan nationalism. Pashtun's ethnic icons and social forms have been believed to be predominantly national culture of dance and music. Ali(1990) argues that, after a Rawalpindi Treaty between the British Indian Government and King Amanullah Khan, Afghanistan has used three different ways to foster the development of a single national image since the 1919 Declaration of Independence. This was the case;

Intensification and expanding of the central government's administrative capacity to facilitate access to different areas of Afghan society.

Achieving a homogeneous educational framework based on national cultures in Afghanistan / Pashtun.

Protection of a broad identity, regardless of ethnic and social diversity. The' Pashtun-based development of the national identity' has not been seen by the Tajik, Uzbek, Hazaras and many other smaller ethnic communities. We were disappointed that we did not recognize or disregard the National Identity Creation process, but they had no space for complaints about it or for access to power and resources outside the contractual areas of the Afghan oligarchy. They did not know their individualities or their absence.

Anderson notes that' the template of government and citizenship is enrolled by the dominant ethnic groups in any authoritarian system, because of the exclusive existence of that kind of rule.' Since the mechanisms of "articulation of value and smoothing change are missing on the stage, the king serves as the ultimate figure who has what and why to represent the different social classes within the power structure" In the absence of 


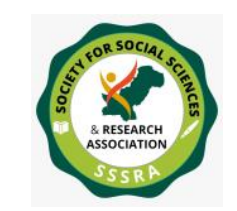

Pak. Journal of Int'L Affairs, Vol 4, Issue 2 (2021)

Ethnic Conflict and the Political Instability ...

political participation, it is also possible in such a policy system to create and perpetuate myths regarding national identity, nationalism and patriotism "(Hobsbawn, 1990).

The world beyond acknowledged Afghanistan's nationalism, its shrink-root historical roots and its courage and tremendous dedication for the defense of its nation (Rubin, 1995). While in Afghanistan, along with educated classes, there was a brawny sense of Afghan national identity in urban areas at least. Nevertheless, this concept has not penetrated into rural society as the issue of greater identity remains "immaterial to their daily realities, and their relation with smaller families, villages, sub-tribes, cities, localities and local communities" (Mousavi, 1998).

\section{Afghanistan may Achieve Political Stability through the Cooperation of Ethnic and Tribal Groups.}

"The United States pursued the time-tested tactic of courting the enemy's allies in its fight against the Taliban after the disaster of 9/11." The Northern Front in Afghanistan has developed as the "natural ally" of the super power by trying to accomplish the same aims as both America's and the Northern Alliance, which have increased the suspicion of the Taliban for their' post-Taliban control structures' among Pashthuns and Taliban past (Rais, 2008). Hamid Karzai (the Pashtun who came from Kandahar, the home town of the taliban) won the Bonn Conference in December 2001. Nevertheless, the perception was that power remained limited to the US-controlled Tajik warlords, since the Karazai is not like a tortoise. At the beginning, it might have carried some weight, yet things have changed with the passage of time. Different reasons for growing ethnic approaches, and they argue that "it is not always a minority that becomes politically divided and oppressed (Nagel and Olzak 1982). Perhaps "any racial or cultural community that has a political advantage in a fraction of a nation's history, but has experienced a decrease in its share of power as their ethnic identity has politized certain social groups" (Haq 1995).

There are five reasons why the Pashtun decline has played its part;

Confining Kabul by an ethnic minority alliance

- Disintégration and conflict of interest between Pashtun groups

- Disengagement of grass-roots opposition parties and society

- Because of solidarity for the Pashtun movement and the connections with such organizations as the Hikmatyar party, the hostile Western attitude to the Pashtun community.

- Power struggle between its neighbors in Afghanistan (Ahady, 1995).

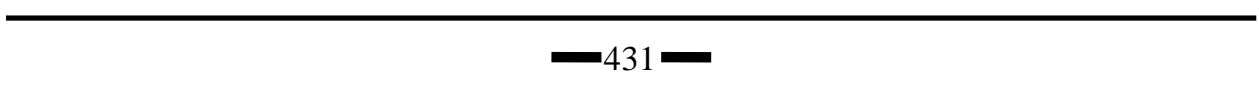




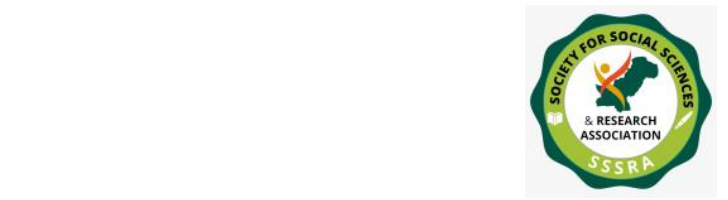

Pak. Journal of Int'L Affairs, Vol 4, Issue 2 (2021)

Ethnic Conflict and the Political Instability ...

It goes beyond saying that the Taliban, and terrorism, are still active today. In a similar vein, the U.S. policy began with the cooperation of ethnic minorities, paying greater attention to ethnic minority leaders than to the Pashtuns for at least three years. The reasons were clear for this inclination or choice. The ethnic minorities headed by the Taliban were more prepared than the Pashtian people to accept and support American forces and establish a strong cultural and political base for the Taliban. In all instances, most tribal leaders and strong local and regional commands from the Pashtoon regions were at the central government side and collaborated with foreign powers, particularly post-Taliban circumstances throughout Afghanistan.

\section{Conclusion}

The ethnic conflicts are a common feature in the multiethnic society of Afghanistan. Yet, in terms of ethnic balance, Afghanistan has been greatly affected by civil war, foreign intervention, and the collapse of the state. Because restoration is the "overarching political topic in Afghanistan," the identity politics is likely to call for reconciliation by recognizing the "veracity of ethnic minority dominance and institutionalized stability and inclusion of all groups in the country's political, economic and cultural existence." Afghanistan and its dominant group, the Pashtuns, should accept the political reason for identity restoration as a "accommodating" and not "unique" amalgamated nationhood. Respect for race and the legitimacy of each group's declaration of independence in all aspects of national life will have positive and promoting political repercussions on freedoms, democracy, sovereignty, and quality and the ability to contribute to the country's power arrangements. With the growth of state power, when restoration programs follow-up positive political results in different fields of national life, ethnic groups may discover a new balance between themselves. With respect to the inner makeup and social structure, none of the large ethnic groups is homogeneous. Yet traditionally, even then, racial loyalties were greater than any other loyalty and had informal degrees of influence between various social classes. If there is cooperation between Afghan ethnic and tribal groups it will help to achieved political stability and peace in Afghanistan. 


\section{Bibliography}

Crews, R. D., \& Tarzi, A. (Eds.). (2009). The Taliban and the crisis of Afghanistan. Harvard University Press.

Hilali, A. Z. (2017). US-Pakistan relationship: Soviet invasion of Afghanistan. Routledge.

Mousavi, S. A. (2018). The Hazaras of Afghanistan. Routledge.

Qassem, A. S. (2016). Afghanistan's political stability: a dream unrealised. Routledge.

Taras, R., \& Ganguly, R. (2015). Understanding ethnic conflict. Routledge.

Ali, S., \& Zafar, Z. (2017). Ethnicity in Afghanistan: Pakistani Factor. Journal of Indian Studies, 3(2), 183-191.

Adeney, K. (2008). Constitutional Design and the Political Salience of "“"Community"” Identity in Afghanistan: Prospects for the Emergence of Ethnic Conflicts in the Post-Taliban Era. Asian Survey, 48(4), 535-557.

Ahady, A. U. H. (1991). Conflict in post-soviet-occupation Afghanistan. Journal of Contemporary Asia, 21(4), 513-528.

Brinkman, H. J., \& Hendrix, C. S. (2011). Food Insecurity and Violent Conflict: Causes. Consequences, and Addressing the Challenges, World Food Prgramme.

Byman, D. L., \& Green, J. D. (1999). The enigma of political stability in the Persian Gulf monarchies. Middle East Review of International Affairs, 3(3), 20-37.

Dupree, N. H. (2004). The family during crisis in Afghanistan. Journal of Comparative Family Studies, 35(2), 311-331.

Enterline, A. J., \& Greig, J. M. (2008). Perfect storms? Political instability in imposed polities and the futures of Iraq and Afghanistan. Journal of Conflict Resolution, 52(6), 880-915.

Glatzer, B. (1998). Is Afghanistan on the brink of ethnic and tribal disintegration?. Fundamentalism reborn, 167-181. 
Mackerras, C. (2001). Xinjiang at the turn of the century: the causes of separatism. Central Asian Survey, 20(3), 289-303.

Omar, M. A. (2015). National unity government: an exceptional outcome to the crisis of the 2014 presidential elections in Afghanistan (Doctoral dissertation, San Francisco State University).

Thier, A., \& Chopra, J. (2002). The road ahead: political and institutional reconstruction in Afghanistan. Third World Quarterly, 23(5), 893-907.

Talentino, Andrea Kathryn. "Nation building or nation splitting? Political transition and the dangers of violence." Terrorism and political violence 21, no. 3 (2009): 378400 .

Wafayezade, M. Q. (2015). Ethnic Politics and Youth Political Participation in Afghanistan. 